Genetic diversity and association analysis of leafminer (Liriomyza langei) resistance in spinach (Spinacia oleracea)

\begin{tabular}{|r|l|}
\hline Journal: & Genome \\
\hline Manuscript ID & gen-2016-0075.R1 \\
\hline Manuscript Type: & Article \\
\hline Date Submitted by the Author: & 18 -May-2016 \\
\hline Complete List of Authors: & $\begin{array}{l}\text { Shi, Ainong; University of Arkansas Fayetteville, Horticulture } \\
\text { Mou, Beiquan; USDA Agricultural Research Service }\end{array}$ \\
\hline Keyword: & $\begin{array}{l}\text { Association mapping, genotyping by sequencing (GBS), Leafminer, single } \\
\text { nucleotide polymorphism (SNP), spinach }\end{array}$ \\
\hline \multicolumn{2}{|l}{} \\
\hline
\end{tabular}

SCHOLARONE ${ }^{\text {M }}$

Manuscripts 


\section{Genetic diversity and association analysis of leafminer (Liriomyza langei) resistance in spinach (Spinacia oleracea)}

Ainong $\mathrm{Shi}^{1}$ and Beiquan $\mathrm{Mou}^{2}$

\footnotetext{
${ }^{1}$ Department of Horticulture, 316 PTSC, University of Arkansas, Fayetteville, AR 72701, USA; ${ }^{2}$ US Department of Agriculture, Agricultural Research Service (USDA-ARS), 1636 E. Alisal Street, Salinas, CA 93905, USA; (Corresponding author A. Shi, E-mail: ashi@uark.edu; and B. Mou, E-mail: Beiquan.Mou@ARS.USDA.GOV)
}

Abstract: Leafminer (Liriomyza langei) is a major insect pest of many important agricultural crops, including spinach (Spinacia oleracea). Use of genetic resistance is an efficient, economic and environment-friendly method to control this pest. The objective of this research was to conduct association analysis and identify single nucleotide polymorphism (SNP) markers associated with leafminer resistance in spinach germplasm. A total of 300 USDA spinach germplasm accessions were used for the association analysis of leafminer resistance. Genotyping by sequencing (GBS) was used for genotyping and 783 SNPs from GBS were used for association analysis. The distribution of leafminer resistance showed a near normal distribution with a wide range from 1.1 to 11.7 stings per square centimeter leaf area, suggesting that the leafminer resistance in spinach is a complex trait controlled by multiple genes with minor effect in this spinach panel. Association analysis indicated that five SNP markers, AYZV02040968_7171, AYZV02076752_412, AYZV02098618_4615, AYZV02147304_383, and AYZV02271373_398 were associated with the leafminer resistance with a LOD 2.5 or higher. The SNP markers may be useful for breeders to select plants and lines for leafminer resistance in spinach breeding programs through marker-assisted selection.

Key words: association mapping, germplasm, genotyping by sequencing (GBS), leafminer, single nucleotide polymorphism (SNP), spinach, Spinacia oleracea 


\section{Introduction}

Leafminers are important insect pests of many agricultural crops throughout the world (Parrella 1987), and major leafminer species affecting vegetables include Liriomyza brassicae (Riley), L. sativae Blanchard, L. trifolii (Burgess), L. huidobrensis (Blanchard), and L. langei Frick. Scheffer et al. (2001) identified the leafminers in the principal spinach production area of central California to be the morphologically cryptic species L. langei by using polymerase chain reaction (PCR) amplification of mitochondrial DNA.

Leafminer adults are small black flies with a bright yellow triangular spot on the upper thorax between the wings. Adult flies puncture leaves to feed on plant sap and females lay white, oval eggs within the leaf tissue. Feeding and oviposition result in leaf damage as "stings" that appear as holes or bumps on the leaves, and adult feeding on cotyledons may stunt seedling growth. Larvae hatch from eggs and feed in leaves, generating the winding, whitish tunnels or mines that are initially narrow, but increase in width as the larvae grow. Larvae drop out of the mines after completing three instars and pupate in the soil or on the leaf surface, and adult flies emerge from pupae in about 8 to 11 days. The entire life cycle can be completed in less than three weeks in warm weather in California and many generations are produced each year. Damages caused by adult sting and larval mining of leaves reduce photosynthetic capacity, render spinach leaves unmarketable, and provide an entrance for disease organisms (LeStrange et al. 1999). About $75 \%$ of the spinach produced in the Salinas Valley is used for fresh market consumption (Monterey County Agricultural Commissioner's Office 2001). The percentage of spinach acreage grown for fresh markets vs. processing markets has increased significantly in the US (Morelock and Correll 2006, 2008). Quality standards for fresh market spinach are 
extremely high, so the leafminer pest poses a serious threat for growers in California and other states who need to produce defect-free products.

Use of host genetic resistance is an alternative strategy to chemical for leafminer management and resistant varieties were recognized as the most economical method to control leafminer in vegetables (Basij et al. 2011). Evaluations of germplasm for leafminer resistance have been conducted in vegetables. Mou and Liu (2003, 2004) screened more than 200 lettuce accessions, found a large range of variation in reactions to leafminer attack, and identified sources of resistance to leafminers. Trumble and Quiros (1988) did not observe any cultivated celery with resistance to leafminers (L. trifolii), but found that an accession of a wild species, Apium prostratum, was immune to the pest. Basij et al. (2011) evaluated leafminer (L. sativae) resistance in 17 cucumber cultivars in greenhouse conditions and found that the 17 cultivars can be divided into four groups: susceptible, semi-susceptible, semi-resistant, and resistant based the indices such as the number of leafminer stings, the number of larval mines, the proportion of larval mines to leafminer stings, and the rate of injury. In spinach, Mou (2008) screened 345 USDA accessions and commercial cultivars for resistance to leafminer, and found that no genotype was immune to leafminers, but significant genotypic differences existed for leafminer stings per unit leaf area, mines per plant, and mines per $100 \mathrm{~g}$ plant weight among the genotypes tested. Mou (2008) also observed some spinach accessions that had much lower levels of leafminer stings and mines than commercial cultivars and reported two accessions PI 274065 and PI 1743854 with the lowest sting density and with the fewest mines per unit plant weight, respectively among genotypes in the field. It has indicated that the leafminer resistant accessions can be used for genetic improvement of spinach for leafminer resistance. So far, two spinach germplasms with resistance to leafminer mines have been released (Mou 2007a, 2007b). 
No information is available for the genetics of leafminer resistance in spinach. Leafminer resistance in spinach seems a complex trait because a large range of responses existed in spinach genotypes (Mou 2008). It would be time-consuming to transfer these complex traits through classic plant breeding approach. However, molecular plant breeding can be an efficient way to select quantitative traits through marker assisted selection (MAS). Single nucleotide polymorphism (SNP), with its abundance, cost efficiency and high-throughput scoring, has become a powerful tool in genome mapping, association studies, diversity analysis, germplasm identification, and tagging of important genes in plant genomics (Collard et al. 2005; Collard and Mackill 2008; Feng et al. 2014; Wang et al. 2015; Xu and Crouch 2008). Therefore, identification of SNP markers associated with leafminer resistance will provide breeders with a useful tool to assist in selecting for insect resistance in spinach breeding programs. Genotyping by sequencing (GBS) is one of the next-generation sequencing platforms to discover SNPs without prior knowledge of the genome in spinach (Elshire et al. 2011; He et al. 2014; Sonah et al. 2013). The spinach genome sequences AYZV01 and AYZV02 are available to the public at (http://www.ncbi.nlm.nih.gov/Traces/wgs/?val=AYZV01 and http://www.ncbi.nlm.nih.gov/Traces/wgs/?val=AYZV02), and represent approximately half of the spinach genome (Dohm et al. 2014; Minoche et al. 2015). In addition, a more comprehensive version of the spinach genome assembly will be made publicly available in 2016 (van Deynze 2014; van Deynze et al. 2015; Allen van Deynze, personal communication). Recently, Xu et al. (2015) reported the comparative transcriptomes of cultivated and wild spinach postulated from RNAseq, assembled 72,151 unigenes and identified a total of $\sim 320,000$ high-quality SNPs and these information can be viewed and downloaded at http://spinachbase.org/cgibin/spinach/index.cgi. Yang et al. (2016) built a spinach genome database SpinachDB 
(http://222.73.98.124/spinachdb), where 21,702 spinach genes were annotated; a total of 131,592 SSRs and 1,125,743 potential SNPs located in 548,801 loci of spinach genome were identified in 11 cultivated and wild spinach cultivars. These resources provide a reference for SNP discovery and association analysis in spinach.

To date, knowledge of the spinach genome is limited and few reports have been published on the use of molecular markers in spinach. Khattak et al. (2006) published a genetic linkage map with six linkage groups, constructing the map with 101 amplified fragment length polymorphisms (AFLPs) and nine simple sequence repeats (SSRs). This genetic map has a total length of $585 \mathrm{cM}$, and an average distance of $5.18 \mathrm{cM}$ between markers, but does not offer a great amount of detail about the linkage groups. AFLPs and SSRs, while useful, are less specific than SNP markers. Recently, Chan-Navarrete et al. (2015) first reported a SNP genetic maps of six linkage groups (P01-P06) consisted of 283 SNP markers, ranging in size from 46 to $116 \mathrm{cM}$ and identified 39 quantitative trait loci (QTLs) related to nitrogen use efficiency (NUE) in spinach. The identification of SNP markers for spinach traits of interest, including insect resistance, will provide breeders with powerful tools to develop improved spinach cultivars more efficiently. Therefore, the development of robust SNP markers and SNP genetic maps would be a valuable resource for spinach breeding efforts. The objective of this research was to conduct association analysis and identify SNP markers associated with leafminer resistance in USDA spinach germplasm.

\section{Materials and methods}

Plant materials 
A total of 300 spinach genotypes were used for the association analysis of leafminer resistance in this study (Supplementary Table S1). The 300 spinach genotypes were USDA spinach germplasm accessions, originally collected from 31 countries, mainly from eight countries including Turkey, United States (US), Afghanistan, Serbia, England, Iran, China, and Belgium having 236 accessions, which consisted of $78.7 \%$ of all tested accessions, and the other 23 countries only had 64 accessions with $21.3 \%$ of the tested accessions (Supplementary Table S1). All seeds were kindly provided by the North Central Regional Plant Introduction Station, USDA-ARS, Iowa State University, Ames, Iowa.

\section{Leafminer phenotyping}

Experiment for leafminer pest evaluation was conducted at the Agricultural Research Station of the USDA, Salinas, California (Mou 2008). Sixteen seeds from each accession were planted in a plastic pot $(10 \cdot 10 \cdot 10 \mathrm{~cm})$ with 2 sand: 1 soil (by volume) in a greenhouse, and seedlings were thinned to 10 plants per pot. Plants were moved into an outdoor insect cage $(2 \mathrm{~m}$ high $\cdot 4 \mathrm{~m}$ wide $\cdot 8 \mathrm{~m}$ deep) made of polypropylene shadecloth for resistance screening 5 weeks after planting. Lettuce leaves with leafminer mines were collected from newly harvested fields around Salinas and hung in the shade to allow leafminer larvae to emerge from the leaves and pupate. Pupae were collected and put in plastic containers to allow adult flies to emerge. Approximately 3500 flies were then released in the outdoor cage to feed on the spinach plants. After $10 \mathrm{~d}$, number of stings per unit area was counted on the leaf with most leafminer stings on each plant using an optical glass binocular magnifier (OptiVisor; Donegan Optical Co., Lenexa, $\mathrm{KS})$.

For each spinach genotype, the stings per square centimeter was accounted based on single plant and total of ten plants in one plot were evaluated. The mean stings per square 
centimeter for each spinach genotype was used for further data analysis. The 'Tabulate' procedure in JMP Genomics 7 (SAS Institute, Cary, NC) and Microsoft (MS) Excel 2013 was used to estimate the average, range, standard deviation (SD), and standard error of leafminer stings per square centimeter leaf area. The distribution of mean leafminer stings per square centimeter in the 300 accessions was drawn using MS Excel.

\section{DNA extraction, GBS, and SNP discovery.}

Genomic DNA was extracted from leaves of spinach plants using the CTAB

(hexadecyltrimethyl ammonium bromide) method (Kisha et al. 1997). DNA library was prepared using the restriction enzyme ApeKI following the GBS protocol described by Elshire et al. (2011). The $90 \mathrm{bp}$ double-end sequencing was performed on each spinach accession using GBS protocol by an Illumina HiSeq 2000 in Genomics Research Institute (BGI) at Hong Kong. GBS data assembly, mapping and SNP discovery were done using SOAP family software (http://soap.genomics.org.cn/) by the bioinformatics team in BGI. The GBS data provided by BGI averaged 3.26 M with $90 \mathrm{bp}$ short-read nucleotides for each spinach sample. The short reads of the GBS data were first aligned to spinach genome reference Viroflay-1.0.1 with AYZV01 project (http://www.ncbi.nlm.nih.gov/Traces/wgs/?val=AYZV01) using SOAPaligner/soap2 (http://soap.genomics.org.cn/). After the Spinach-1.0.3 spinach genome reference released on July 22, 2015, the AYZV01 series of contig accessions were changed to AYZV02 accessions (http://www.ncbi.nlm.nih.gov/Traces/wgs/?val=AYZV02), all SNP information was updated to AYZV02 version. The two versions of spinach genome references were also published on web site at http://bvseq.molgen.mpg.de/Genome/Download/Spinach/. The SOAPsnp v 1.05 was used for SNP calling (Li 2011; Li et al. 2009). Approximately one half-million SNPs were discovered from the GBS data among the 300 spinach germplasm accessions and provided by BGI. The 
spinach accessions and SNPs were filtered before conducting genetic diversity and association analyses. If the spinach accession had greater than 20\% missing SNP data and the heterozygous SNP genotype $>30 \%$, the spinach genotype was removed from the panel. The SNP data were filtered by minor allele frequency $(\mathrm{MLF})>2 \%$, missing data $<7 \%$, and heterozygous genotype $<$ 20\%. After filtering, 783 SNPs for 300 spinach accessions were used for genetic diversity and association analysis.

\section{Population structure and genetic diversity}

The model-based program STUCTURE 2.3.4 (Pritchard et al. 2000) was used to assess the population structure of the 300 spinach accessions/cultivars based on 783 loci. In order to identify the number of populations $(\mathrm{K})$ making up the structure of the data, the burn-in period was set at 10,000 with the Markov Chain Monte Carlo iterations and the run length set at 20,000 in an admixture model. The analysis then correlated allele frequencies which was independent for each run ( $\mathrm{Lv}$ et al. 2012). Ten runs were performed for each simulated value of K, which ranged from 1 to 11 . For each simulated $\mathrm{K}$, the statistical value delta $\mathrm{K}$ was calculated using the formula described by Evanno et al. (2005). The optimal K was determined using STRUCTURE HARVESTER (Earl and von Holdt, 2012; http://taylor0.biology.ucla.edu/structureHarvester/). After the optimal K was determined, a Q-matrix was obtained and was used in TASSEL 5 for association analysis. Each spinach accession was then assigned to a cluster (Q) based on the probability determined by the software that the genotype belonged in the cluster. The cut-off probability for assignment to a cluster was 0.5225 for only two clusters (structure populations). Based on the optimum K, a Bar plot with 'Sort by Q' was obtained to show the visual population structure among the 300 spinach accessions. 
Genetic diversity was also assessed and the phylogeny trees were drawn using MEGA 6 (Tamura et al. 2013) based on the Maximum Likelihood tree method with the following parameters. Test of Phylogeny: Bootstrap Method, No. of Bootstrap Replications: 500, Model/Method: General Time Reversible model, Rates among Sites: Gamma distributed with Invariant sites $(\mathrm{G}+\mathrm{I})$, Number of Discrete Gamma Categories: 4, Gaps/Missing Data Treatment: Use all sites, ML Heuristic Method: Subtree-Pruning-Regrafting-Extensive (SPR level 5), Initial Tree for ML: Make initial tree automatically (Neighbor Joining), and Branch Swap Filter: Moderate. In order to compare the results from the two software programs, during the drawing of the phylogeny trees by MEGA, the colored shape and branch of each spinach genotype was drawn using the same color which was located at the cluster (Q) from STRUCTUR. For sub-tree of each Q (cluster), the shape of 'Node/Subtree Marker' and the 'Branch Line' was drawn with the same color as in the figure of the Bar plot of the population clusters from the STRUCTURE analysis.

\section{Association analysis}

Association analysis was performed using TASSEL 5 software, in which the single marker regression (SMR) without structure and without kinship, the general linear model (GLM), and the mixed linear model (MLM) methods as described in TASSEL 5 (Bradbury et al. 2007; http://www.maizegenetics.net/tassel). Population structure (Q) was estimated using STUCTURE 2.3.4 (Pritchard et al. 2000), and Kinship (K) was estimated by the tool Kinship with Scald_IBS method built in Tassel 5.

\section{Results}




\section{Phenotyping of leafminer resistance}

None of the genotypes tested was immune to leafminers, because all genotypes had at least a few stings. Significant genotypic differences were found for leafminer stings per unit leaf area (Supplementary Table S1). Leafminer stings per square centimeter leaf area ranged from 1.1 to 11.7 and averaged 5.2 with a near normal distribution (Table S1; Fig. 1), suggesting that the leafminer resistance in spinach is a complex trait controlled by multiple genes with minor effect in the spinach panel. The standard deviation was 1.73 with the standard error 0.0058 , indicating that there were significant genetic differences of leafminer resistance among the 300 spinach accessions (Table S1).

\section{Genetic diversity and population structure}

The population structure of the 300 spinach accessions was initially inferred using STRUCTURE 2.3.4 (Pritchard et al. 2000) and the peak of delta $\mathrm{K}$ was observed at $\mathrm{K}=2$, indicating the presence of two main populations (clusters, Q1 and Q2) in the spinach panel (Fig. 2A and $2 \mathrm{~B})$. The classification of accessions into populations based on the model-based structure from STRUCTURE 2.3.4 was shown in Fig. 2B and Table S1. We used Q-value $=0.525$ as the value to divide the clusters, i.e. if a spinach had its Q1 value $>=0.525$, it would be divided into the Cluster Q1; else if its Q2 value >=0.525, it would be divided into the Cluster Q2; and the leftover $(0.475<\mathrm{Q} 1<0.525$ or $0.475<\mathrm{Q} 2<0.525)$ would be into Q1Q2 of the admixture. In total 286 accessions (95.3\%) were assigned to one of the two populations (Q1 or Q2). Population 1 and 2 (Q1 and Q2) consisted of $103(34.3 \%)$ and $186(61.0 \%)$ accessions, respectively. The remaining 14 accessions (4.7\%) were categorized as having admixed ancestry between Q1 and Q2 called Q1Q2 (Table S1). 
The genetic diversity among spinach accessions was also assessed using the Maximum Likelihood (ML) method by MEGA 6 (Tamura et al. 2013). We defined Q1 and Q2 as the two main clusters and used the same colors as the population structure Q1 (red) and Q2 (green) from the STRUCTURE 2.3.4 (Fig. 2B) to draw the subtrees of the phylogenetic tree (Fig. 2C) with Q1 (red and round shape), Q2 (green and square shape), and the admixture Q1Q2 (black empty square). Two phylogenetic trees were included: (1) Fig. 2C, without taxon names in order to compare it to the structure populations from STRUCTURE and view them easily and clearly; (2) Supplementary Fig. S1: the format of the traditional rectangular phylogenetic tree with taxon name. The phylogenetic trees from MEGA 6 (Fig. 2C and Fig. S1), were good but not fully consistent with the structure populations (Q1-Q2) from STRUCTURE 2.3.4 (Fig. 2A and 2B), indicating that there were two differentiated genetic populations and admixtures in the spinach panel, which was not completely divided into two clusters.

\section{Association analysis}

Based on the genetic diversity analysis from STRUCTURE and MEGA and viewing the phylogenetic tress from Figs. 2 and Fig. S1, the 300 spinach accessions can be organized into two structured populations. Therefore, we used the $\mathrm{Q}$ matrix with two structures in the association mapping in TASSEL. In total, three models in TASSEL were used to do association analysis of leafminer resistance, including SMR, GLM (Q) and MLM (Q+K). We also used a LOD value (or likely LOD $=\sim(-\operatorname{LOG}(\mathrm{P})$, where $\mathrm{P}$ is the $\mathrm{P}$ value $)$ having equaled or greater than 2.5 as the threshold value to identify the SNP marker associated with the leafminer resistance in the study. 
With LOD value of 2.5 or higher in all three models (SMR, GLM and MLM) from TASSEL, there were five SNPs showed to be associated with leafminer resistance (Table 1). Among the five SNP markers, AYZV02040968_7171, AYZV02076752_412, and AYZV02271373_398 had 2.6 or higher LOD values in all three models, and AYZV02098618_4615 and AYZV02147304_383 had a 2.5 or higher LOD in both SMR and GLM models and a 2.2 LOD value in MLM model, indicating that the five SNP markers were associated with the leafminer resistance. However, the $\mathrm{R}^{2}$ values were very low from 3.5 to $5.5 \%$ for all five SNP markers in three models (Table 1), indicating that the markers had minor effect for the leafminer resistance. The five SNPs were located at five different contigs, which may be located at different chromosomes or different regions of chromosomes, furtherly suggesting leafminer resistance was a quantitative trait controlled by multiple genes with minor effect.

\section{Discussion}

From this research, the distribution of leafminer resistance in the tested 300 spinach genotypes showed a near normal distribution with a wide range from 1.1 to 11.7 leafminer stings per square centimeter leaf area, suggesting that the leafminer resistance in spinach was a complex trait governed by multiple genes with minor effect. Mou (2008) reported that no genotype was immune to leafminers, but significant genotypic differences were found for leafminer stings per unit leaf area, mines per plant, and mines per $100 \mathrm{~g}$ plant weight among the spinach genotypes tested. So far, it is not clear whether the leafminer resistance in spinach is a quantitative or qualitative trait controlled by major genes or minor genes. We did not find major QTLs for leafminer resistance in this study. All identified SNP markers had very low R-square values, further indicating that there were multiple genes with minor effect existed in these 
spinach genotypes for controlling leafminer resistance. But there is no evidence either to deny that major genes exist or do not exist for leafminer resistance in spinach. For resistance to similar pest caused by Liriomyza spp. in other crops, major genes were identified. Dogimont et al. (1999) reported a dominant gene, $L t$ for leafminer ( $L$. trifolii) resistance in melon based on F2 and back-cross progenies from a cross between a resistant line Nantais Oblong and Vedrantais, a Charentais line susceptible to the leafminer. However, Kennedy et al. (1978) reported that two melon accessions PI 282448 and PI 313970 had recessive, or incompletely dominant resistance to another leafminer species (L. sativae). In other reports, QTL and multiple genes were also identified for leafminer resistance, such as Moreira et al. (1999) identified one major QTL for leafminer resistance located on chromosome 2 using Random Amplified Polymorphic DNA (RAPD) and Restriction Fragment Length Polymorphism (RFLP) markers, and Cardoso et al. (2014) identified four candidate genes for coffee leafminer resistance. Further QTL mapping using bi-parent populations derived from highly susceptible and highly resistant spinach lines will confirm the genetics of resistance to leafminer resistance in spinach.

In this study, there was no replicates for the phenotyping experiment with the 310 spinach genotype, however, three experiments have been conducted for evaluation of leafminer resistance in spinach germplasm: one in cage and two in field during the year 2002 and 2004 (Mou 2008). The leafminer stings per square centimeter leaf area in spinach was found to be a very stable trait with strong correlations among the three experiments (Mou 2008). Mou (2008) identified the correlation coefficients (r) to be $0.770,0.746$, and 0.802 between cage and 2002 field, between cage and 2004 field, and between 2002 field and 2004 field, respectively.

Three models SMR, GLM, and MLM were used to conduct association analysis of leafminer resistance in this study. We observed that a lot of SNP showed different results in 
different models (data not shown). We supposed that if it gave significant association in different models, the SNP marker should be a reliable one. Based on LOD $(-\log (\mathrm{P}))$ values with 2.5 or higher in three models, five SNP markers were identified to be strongly associated with leafminer resistance from this study (Table 1), indicating that the three SNP markers may be used as reliable molecular markers in breeding programs through MAS.

Among the 300 spinach genotypes, six accessions, PI220121, PI274059, PI358248, PI445783, PI449353, and PI531454 had 2.0 or fewer mean stings per square centimeter leaf area. In addition, NSL6093, PI274065, PI358253, and PI531449 also had fewer mean stings per square centimeter leaf area across three experiments (Mou 2008). The ten accessions showed high resistance to leafminer and they may be used as parents in spinach breeding programs to develop leafminer resistant cultivars. Using different genetic sources will allow breeders to create a wider range of variation in a given trait among progeny derived from two parents with a broader genetic background or larger genetic distance. A phylogenetic tree among the ten spinach accessions was built using 783 SNP alleles by MEGA 6 (Fig. 3). From the phylogenetic tree, the accession PI274065 from England is merged to PI531449 from Hungary, closer to PI531454 (country: Hungary), and then clustered together with PI274059 (England) and PI449353 (Turkey); the two accessions, PI358248 (Serbia) and PI445783 (Syria) are merged together and closer to above cluster with the five accessions; another two accessions PI220121 (Afghanistan) and PI358253 (Serbia) merged together as a separate group; and the Illinois accession NSL6093 doesn't merged to anyone as a outlier but closer to PI220121 and PI358248 (Fig. 3). The phylogenetic analysis provides breeders with knowledge about how to select the ten leafminer resistant accessions in breeding program. Thus, these accessions may provide good sources of leafminer resistance to be used as parents in spinach breeding. 


\section{Acknowledgments}

This work is supported, in part, by the USDA National Institute of Food and Agriculture Hatch project accession number 1002423.

\section{References}

Basij, M., Askarianzaeh, A., Asgari, S., Moharramipou, S., and Rafezi, R. 2011. Evaluation of resistance of cucumber cultivars to the vegetable leafminer (Liriomyza sativae Blanchard) (Diptera: Agromyzidae) in greenhouse. Chilean J Agri. Res. 71: 395-400.

Bradbury, P.J., Zhang, Z., Kroon, D.E., Casstevens, T.M., Ramdoss, Y., and Buckler, E.S. 2007. TASSEL: software for association mapping of complex traits in diverse samples. Bioinformatics 23: 2633-2635. doi:10.1093/bioinformatics/btm308.

Cardoso, D.C., Martinati, J.C., Giachetto, P.F., Vidal, R.O., Carazzolle, M.F., Padilha, L., Guerreiro-Filho, O., and MalufEmail, M.P. 2014. Large-scale analysis of differential gene expression in coffee genotypes resistant and susceptible to leaf miner-toward the identification of candidate genes for marker assisted-selection. BMC Genomics 15: 66. doi:10.1186/1471-2164-15-66.

Chan-Navarrete, R., Dolstra, O., van Kaauwen, M., van Bueren, E.T.L., and van der Linden, C.G. 2016. Genetic map construction and QTL analysis of nitrogen use efficiency in spinach (Spinacia oleracea L.). Euphytica 208: 621-636.

Collard, B.C.Y., Jahufer, M.Z.Z., Brouwer, J.B., and Pang, E.C.K. 2005. An introduction to markers, quantitative trait loci (QTL) mapping and marker-assisted selection for crop improvement: The basic concepts. Euphytica 142: 169-196.

Collard, B.C.Y., and Mackill, D.J. 2008. Marker-assisted selection: an approach for precision plant breeding in the twenty-first century. Phil. Trans. R. Soc. B12 363: 557-572.

Dogimont, C., Bordat, D., Pages, C., Boissot, N., and Pitrat, M. 1999. One dominant gene conferring the resistance to the leafminer, Liriomyza trifolii (Burgess) Diptera: Agromyzidae in melon (Cucumis melo L.). Euphytica 105: 63-67. 
Dohm, J.C. et al. 2014. The genome of the recently domesticated crop plant sugar beet (Beta vulgaris). Nature 505: 546-549. doi:10.1038/nature12817.

Earl, D.A., and von Holdt, B.M. 2012. STRUCTURE HARVESTER: a website and program for visualizing STRUCTURE output and implementing the Evanno method. Conservation Genet. Resources 4: 359-361. Doi:10.1007/s12686-011-9548-7.

Elshire, R.J., Glaubitz, J.C., and Sun, Q. 2011. A robust, simple genotyping-by-sequencing (GBS) approach for high diversity species. PLoS ONE 6(5): e19379. doi:10.1371/journal.pone.0019379.

Evanno, G., Regnaut, S., and Goudet, J. 2005. Detecting the number of clusters of individuals using the software STRUCTURE: a simulation study. Mol. Ecol. 14: 2611-2620. doi:10.1111/j.1365-294X.2005.02553.x.

Fang, W.P., Meinhardt, L.W., Tan, H., Zhou, L., Mischke, S., and Zhang, D. 2014. Varietal identification of tea (Camellia sinensis) using nanofluidic array of single nucleotide polymorphism (SNP) markers. Horticulture Research 1: 14035. doi: 10.1038/hortres.2014.35.

He, J., Zhao, X., Laroche, A., Lu, Z., Liu, H., and Li, Z. 2014. Genotyping-by-sequencing (GBS), an ultimate marker-assisted selection (MAS) tool to accelerate plant breeding. Front. Plant Sci. 5: 484. doi:10.3389/fpls.2014.00484.

Kennedy, G.G., Bohn, G.W., Stoner, A.K., and Webb, R.E. 1978. Leafminer resistance in muskmelon. J Amer Soc Hort Sci 103: 571-574.

Khattak, J., Torp, A.M., and Andersen, S.B. 2006. A genetic linkage map of Spinacia oleracea and localization of a sex determination locus. Euphytica 148: 311-318.

Kisha, T., Sneller, C.H., and Diers, B.W. 1997. Relationship between genetic distance among parents and genetic variance in populations of soybean. Crop Sci. 37: 1317-1325.

LeStrange, M., Koike, S., Valencia, J., and Chaney, W. 1999. Spinach production in California. University of California, Division of Agriculture and Natural Resources. Publication 7212, pp. 3-4.

Li, H. 2011. A statistical framework for SNP calling, mutation discovery, association mapping and population genetical parameter estimation from sequencing data. Bioinformatics 27: 2987-2993. doi:10.1093/bioinformatics/btr509. 
Li, R., Yu, C., Li, Y., Lam, T., Yiu, S., Kristiansen, K., and Wang, J. 2009. SOAP2: An improved ultrafast tool for short read alignment. Bioinformatics 25: 1966-1967. doi:10.1093/bioinformatics/btp336.

Lv, J., Qi, J., Shi, Q., Shen, D., Zhang, S., Zhang, A., Shao, G., Li, H., Sun, Z., Weng, Y., Shang, Y., Gu, X., Li, X., Zhu, X., Zhang, J., van Treuren, R., van Dooijeweert, W., Zhang, Z., and Huang, S. 2012. Genetic diversity and population STRUCTURE of cucumber (Cucumis sativus L). PLoS ONE 7: 46919. doi:10.1371/journal.pone.0046919.

Minoche, A.E., Dohm, J.C., Schneider, J., Holtgrawe, D., Viehover, P., Montfort, M., Sorensen, T.R., Weisshaar, B., and Himmelbauer, H. 2015. Exploiting single-molecule transcript sequencing for eukaryotic gene prediction. Genome Biol. 16: 184. doi:10.1186/s13059-0150729-7

Monterey County Agricultural Commissioner's Office. 2001. Vegetable crops. Monterey County Crop Report 2000, pp. 6.

Moreira, L.A., Mollema, C., and van Heusden, S. 1999. Search for molecular markers linked to Liriomyza trifolii resistance in tomato. Euphytica 109: 149-156.

Morelock, T.E., and Correll, J.C. 2006. History of spinach production in the United States. Page 16, in: Proc. 2006 Internat. Spinach Conf, 13-14 July 2006, La Conner, WA.

Morelock, T.E., and Correll, J.C. 2008. Spinach. In Vegetables I: Asteraceae, Brassicaceae, Chenopodiaceae, and Cucurbitaceae. Edited by J. Prohens and F. Nuez. Springer, New York. Pp. 189-218.

Mou, B. 2007a. Leafminer-resistant spinach germplasm 03-04-9. HortScience 42: 699-700.

Mou, B. 2007b. Leafminer-resistant spinach germplasm 03-04-63. HortScience 42: 1717-1718

Mou, B. 2008. Leafminer resistance in spinach. HortScience 43: 1716-1719.

Mou, B., and Liu, Y.B. 2003. Leafminer resistance in lettuce. HortScience 38: 570-572.

Mou, B., and Liu, Y.B. 2004. Host plant resistance to leafminers in lettuce. J. Amer. Soc. Hort. Sci. 129: 383-388.

Parrella, M.P. 1987. Biology of Liriomyza. Annu. Rev. Entomol. 32: 201-224.

Pritchard, J.K., Stephens, M., and Donnelly, P. 2000. Inference of population structure using multilocus genotype data. Genetics 155: 945-959.

Scheffer, S.J., Wijesekara, A., Visser, D., and Hallett, R.H. 2001. Polymerase chain reaction restriction fragment-length polymorphism method to distinguish Liriomyza huidobrensis from 
L. langei (Diptera: Agromyzidae) applied to three recent leafminer invasions. J. Econ.

Entomol. 94: 1177-1182.

Sonah, H., Bastien, M., Iquira, E., Tardivel, A., and Legare, G. 2013. An improved genotyping by sequencing (GBS) approach offering increased versatility and efficiency of SNP discovery and genotyping. PLoS ONE 8: 54603. doi:10.1371/journal.pone.0054603.

Tamura, K., Stecher, G., Peterson, D., Ailipski, A., and Kumar, S. 2013. MEGA6: Molecular evolutionary genetics analysis version 6.0. Mol. Biol. Evolution 30: 2725-2729. doi:10.1093/molbev/mst197.

van Deynze, A. 2014. A de novo draft assembly of spinach using Pacific Biosciences technology. Plant \& Animal Genomics XXII Conference, 10-15 January, 2014. San Diego, CA. Available at http://aa314.gondor.co/webinar/a-de-novo-draft-assembly-of-spinach-usingpacific-biosciences-technology/ [accessed on March 3, 2016].

van Deynze, A., Ashrafi, H., Hickey, L., Peluso, P., Rank, D., Chin, J., Rapicavoli, N., Drake, J., Garvin, T., and Schatz, M. 2015. Using spinach to compare technologies for whole genome assemblies. Plant \& Animal Genomics XXIII Conference, 10-14 January, 2015. San Diego, CA.

Wang, B., Tan, H., Fang, W., Meinhardt, L.W., Mischke, S., Matsumoto, T., and Zhang, D. 2015. Developing single nucleotide polymorphism (SNP) markers from transcriptome sequences for identification of longan (Dimocarpus longan) germplasm. Horticulture Research 2: 14065.

Xu, C., Jiao, C., Zheng, Y., Sun, H., Liu, W., Cai, X., Wang, X., Liu, S., Xu, Y., Mou, B., Dai, S., Fei, Z., and Wang, Q. 2015. De novo and comparative transcriptome analysis of cultivated and wild spinach. Scientific Reports 5: 17706. doi:10.1038/srep17706.

$\mathrm{Xu}, \mathrm{Y}$. , and Crouch, J.H. 2008. Marker-assisted selection in plant breeding: from publications to practice. Crop Sci. 48: 391-407.

Yang, X., Tan, H., and Zhu, W. 2016. SpinachDB: A well-characterized genomic database for gene family classification and SNP information of spinach. PLoS ONE 11(5): e0152706. doi:10.1371/journal.pone.0152706. 
Table 1. Five SNP markers associated with leaf miner resistance identified from three modes using Tassel in 300 spinach accessions.

\begin{tabular}{|c|c|c|c|c|c|c|c|c|c|c|c|}
\hline \multicolumn{4}{|c|}{ Spinach genome Spinach-1.0.3 information } & \multicolumn{2}{|c|}{ Viroflay-1.0.1 } & \multicolumn{3}{|c|}{ LOD (-LOG(P)) } & \multicolumn{3}{|c|}{$\mathbf{R}^{2}(\%)$} \\
\hline SNP name ${ }^{a}$ & $\begin{array}{l}\text { SNP } \\
\text { Type }\end{array}$ & $\begin{array}{c}\text { Contig at } \\
\text { AYZV02 } \\
\text { project }\end{array}$ & $\begin{array}{c}\text { SNP } \\
\text { Position }\end{array}$ & $\begin{array}{c}\text { Contig at } \\
\text { AYZV01 } \\
\text { project }\end{array}$ & $\begin{array}{c}\text { SNP } \\
\text { Position }\end{array}$ & $S_{M} R^{b}$ & GLM $^{b}$ & $M^{\prime} M^{b}$ & SMR & GLM & MLM \\
\hline AYZV02040968_7171 & $\mathrm{C} / \mathrm{T}$ & AYZV02040968 & 7171 & AYZV01031587 & 7171 & 3.4 & 3.5 & 2.7 & 5.3 & 5.3 & 4.2 \\
\hline AYZV02076752_412 & $T / G$ & AYZV02076752 & 412 & AYZV01058628 & 412 & 2.9 & 2.9 & 3.0 & 4.3 & 4.3 & 4.7 \\
\hline AYZV02098618_4615 & $\mathrm{T} / \mathrm{C}$ & AYZV02098618 & 4615 & AYZV01074880 & 4615 & 3.5 & 3.5 & 2.2 & 5.5 & 5.4 & 3.5 \\
\hline AYZV02147304_383 & $\mathrm{T} / \mathrm{C}$ & AYZV02147304 & 383 & AYZV01109497 & 383 & 2.5 & 2.5 & 2.2 & 3.7 & 3.7 & 3.5 \\
\hline AYZV02271373_398 & $\mathrm{A} / \mathrm{G}$ & AYZV02271373 & 398 & AYZV01198119 & 398 & 2.6 & 2.7 & 3.1 & 4.2 & 4.3 & 5.1 \\
\hline
\end{tabular}

${ }^{a}$ SNP name is defined as the contig name plus the SNP position on the contig.

${ }^{\mathrm{b}} \mathrm{SMR}=$ single marker regression); GLM = general linear model; and MLM = mixed linear model using TASSEL 5 (Bradbury et al. 2007; http://www.maizegenetics.net/tassel). 
Fig. 1. The distribution of mean leafminer stings per square centimeter leaf area in 300 spinach germplasm accessions.

Fig. 2. Model-based populations in the association panel: (A) Delta K values for different numbers of populations assumed (K) in the STRUCTURE analysis. (B) Classification of 300 USDA spinach accessions into two populations using STRUCTURE 2.3.4. The distribution of the accessions to different populations is indicated by the color code (Q1: red and Q2: green). (C) Maximum Likelihood (ML) tree of the 300 accessions drawn by MEGA 6. The color codes for each population are consistent in the figure $\mathrm{B}$ and $\mathrm{C}$, and the empty black square as the admixture Q1Q2.

Fig. 3. A phylogenetic tree drawn by MEGA 6 among ten spinach germplasm accessions with low mean stings per square centimeter leaf area. 


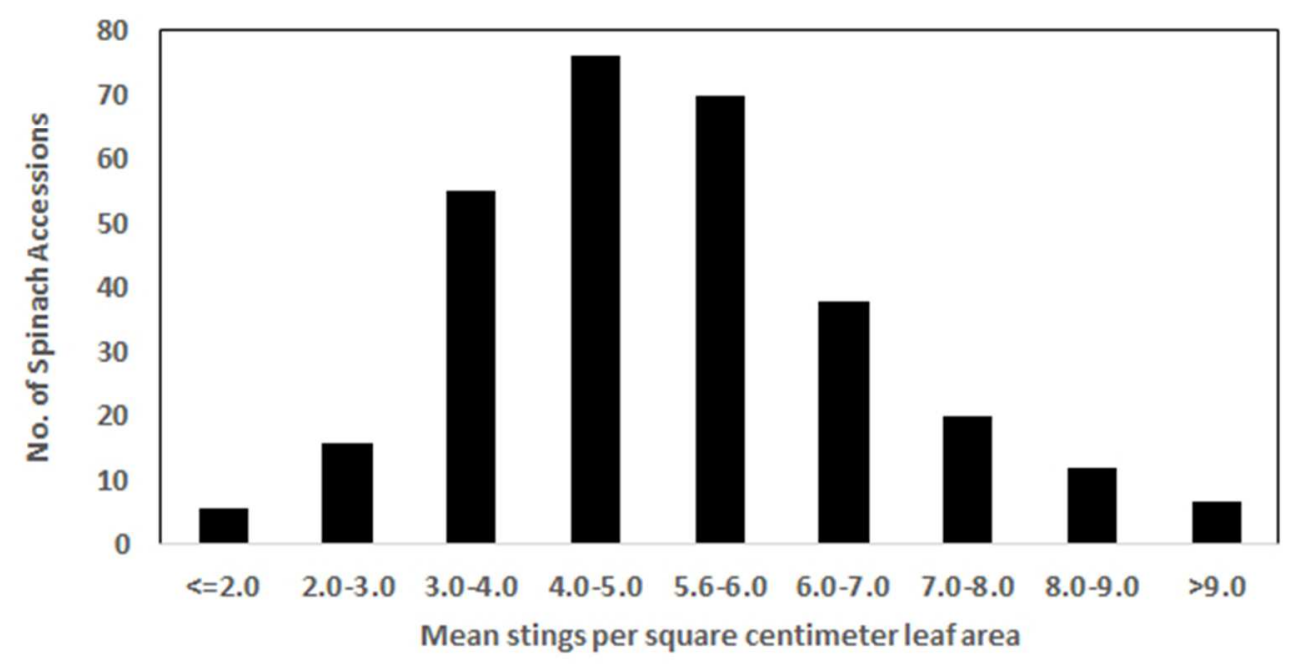

Fig. 1

$154 \times 80 \mathrm{~mm}(96 \times 96 \mathrm{DPI})$ 


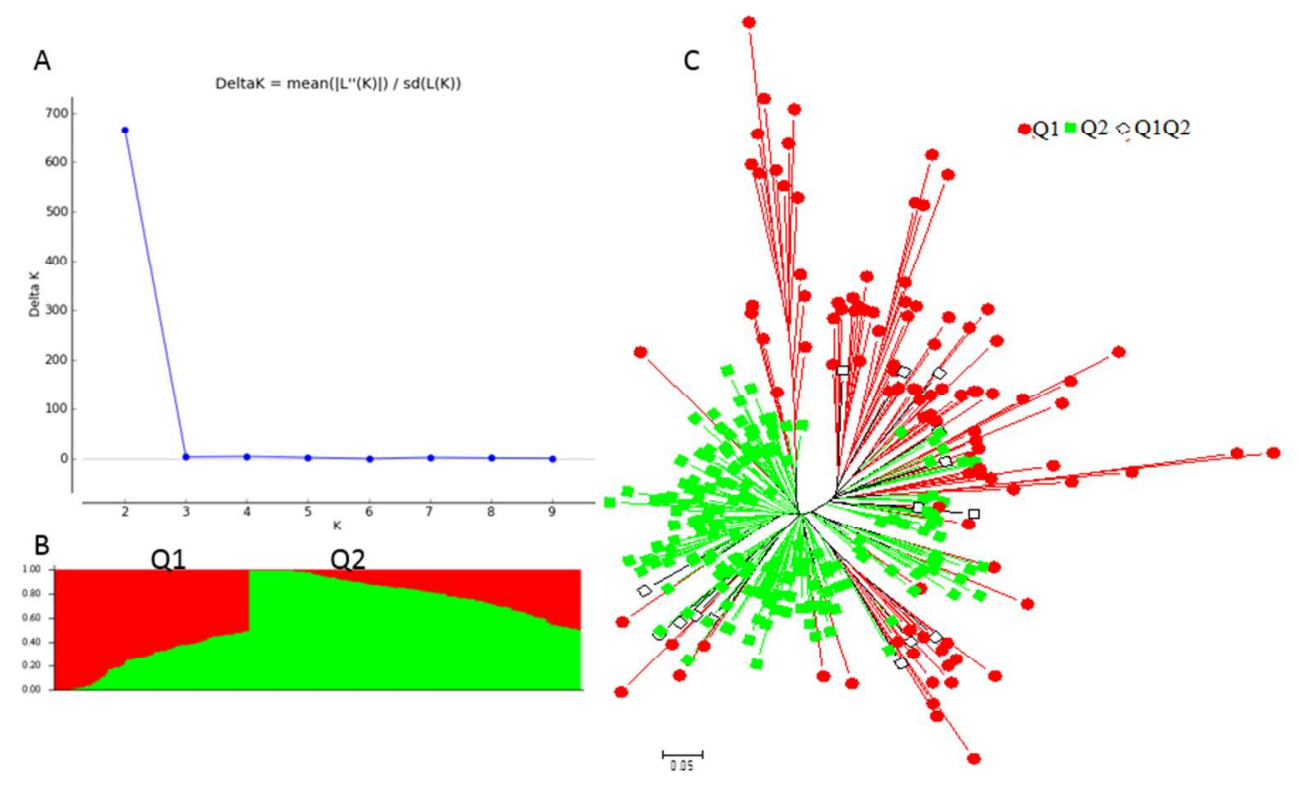

Fig. 2

$243 \times 147 \mathrm{~mm}(96 \times 96$ DPI) 


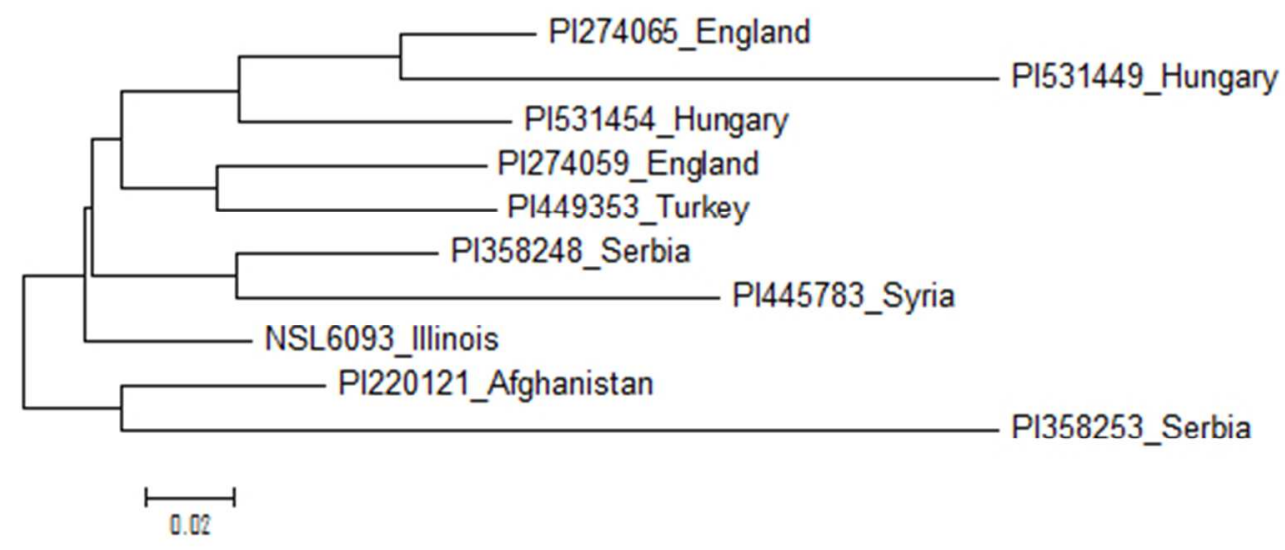

Fig.3

$140 \times 60 \mathrm{~mm}(96 \times 96 \mathrm{DPI})$ 
Supplementary Table S1. Spinach accession, original country and States in US, leafminer damage (mean strings per square centimeter leaf area), and cluster assigned in this study.

\begin{tabular}{|c|c|c|c|c|c|}
\hline $\begin{array}{c}\text { Accession } \\
\text { No. }\end{array}$ & $\begin{array}{l}\text { Original } \\
\text { country }\end{array}$ & $\begin{array}{l}\text { US } \\
\text { State }\end{array}$ & $\begin{array}{c}\text { Leaf } \\
\text { damge }^{\mathrm{a}}\end{array}$ & $\begin{array}{l}\text { Q- } \\
\text { cluster }^{b}\end{array}$ & LineID $^{c}$ \\
\hline Ames23662 & Afghanistan & & 4.5 & Q2 & Ames.23662_Afghanistan_Q2 \\
\hline NSL184378 & US & Oregon & 4.1 & Q1 & NSL184378_Oregon_Q1 \\
\hline NSL184380 & US & California & 4.9 & Q1 & NSL184380_California_Q1 \\
\hline NSL184398 & US & California & 3.5 & Q2 & NSL184398_California_Q2 \\
\hline NSL186328 & US & Oregon & 3.2 & Q2 & NSL186328_Oregon_Q2 \\
\hline NSL22003 & US & California & 5 & Q1 & NSL22003_California_Q1 \\
\hline NSL22149 & US & California & 5.9 & Q2 & NSL22149_California_Q2 \\
\hline NSL26513 & US & Michigan & 4.4 & Q1 & NSL26513_Michigan_Q1 \\
\hline NSL32629 & US & Louisana & 3.2 & $\mathrm{Q} 1$ & NSL32629_Louisana_Q1 \\
\hline NSL32678 & US & NewYork & 4.7 & $\mathrm{Q} 2$ & NSL32678_NewYYork_Q2 \\
\hline NSL37031 & US & Georgia & 4 & Q1 & NSL37031_Georgia_Q1 \\
\hline NSL40592 & US & Michigan & 5.9 & $\mathrm{Q} 2$ & NSL40592_Michigan_Q2 \\
\hline NSL4683 & US & Maryland & 2.8 & Q2 & NSL4683_Maryland_Q2 \\
\hline NSL6082 & US & NewYork & 4.2 & $\mathrm{Q} 2$ & NSL6082_NewYork_Q2 \\
\hline NSL6083 & US & Illinois & 5.6 & $\mathrm{Q} 2$ & NSL6083_Illinois_Q2 \\
\hline NSL6084 & US & California & 4.7 & Q1Q2 & NSL6084_California_Q1Q2 \\
\hline NSL6085 & US & California & 2.9 & Q1Q2 & NSL6085_California_Q1Q2 \\
\hline NSL6086 & US & California & 7.3 & Q2 & NSL6086_California_Q2 \\
\hline NSL6087 & US & NewYork & 5.1 & Q1 & NSL6087_NewYork_Q1 \\
\hline NSL6088 & US & NewYork & 5.3 & Q1 & NSL6088_NewYork_Q1 \\
\hline NSL6089 & US & Missouri & 7.6 & $\mathrm{Q} 2$ & NSL6089_Missouri_Q2 \\
\hline NSL6090 & US & Pennsylvania & 5 & Q2 & NSL6090_Pennsylvania_Q2 \\
\hline NSL6092 & US & NewYork & 4.3 & Q2 & NSL6092_NewYork_Q2 \\
\hline NSL6093 & US & Illinois & 2.9 & Q2 & NSL6093_Illinois_Q2 \\
\hline NSL6094 & US & Pennsylvania & 5.9 & Q1 & NSL6094_Pennsylvania_Q1 \\
\hline NSL6095 & US & Missouri & 3.1 & Q1 & NSL6095_Missouri_Q1 \\
\hline NSL6096 & US & Missouri & 6 & Q1 & NSL6096_Missouri_Q1 \\
\hline NSL6097 & US & Minnesota & 4.1 & Q1 & NSL6097_Minnesota_Q1 \\
\hline NSL6098 & US & Virginia & 4.6 & Q1 & NSL6098_Virginia_Q1 \\
\hline NSL6099 & US & Pennsylvania & 7.1 & Q1 & NSL6099_Pennsylvania_Q1 \\
\hline NSL6557 & US & Washington & 4.9 & Q1 & NSL6557_Washington_Q1 \\
\hline NSL65915 & US & Oregon & 4.2 & Q1 & NSL65915_Oregon_Q1 \\
\hline NSL6782 & Netherlands & & 4.2 & Q1 & NSL6782_Netherlands_Q1 \\
\hline NSL68263 & US & NewYork & 4.1 & Q2 & NSL68263_NewYYork_Q2 \\
\hline NSL81328 & US & Maryland & 4.2 & Q1 & NSL81328_Maryland_Q1 \\
\hline NSL92009 & US & YorkNew & 6.1 & Q2 & NSL92009_YorkNew_Q2 \\
\hline NSL92513 & US & Oregon & 5.8 & Q1 & NSL92513_Oregon_Q1 \\
\hline PI103063 & China & & 5.8 & Q2 & PI103063_China_Q2 \\
\hline
\end{tabular}




\begin{tabular}{|c|c|c|c|c|c|}
\hline PI163309 & India & & 5.6 & Q2 & PI163309_India_Q2 \\
\hline PI164965 & Turkey & & 3.9 & Q1Q2 & PI164965_Turkey_Q1Q2 \\
\hline PI164966 & Turkey & & 3.6 & $\mathrm{Q} 2$ & PI164966_Turkey_Q2 \\
\hline PI165012 & Turkey & & 4.3 & Q1 & PI165012_Turkey_Q1 \\
\hline PI165560 & India & & 8.3 & Q2 & PI165560_India_Q2 \\
\hline PI165710 & Japan & & 4.3 & Q2 & PI165710_Japan_Q2 \\
\hline PI165994 & India & & 5.9 & Q1 & PI165994_India_Q1 \\
\hline PI167098 & Turkey & & 6.3 & Q1 & PI167098_Turkey_Q1 \\
\hline PI167194 & Turkey & & 3.5 & Q1 & PI167194_Turkey_Q1 \\
\hline PI167195 & Turkey & & 5.6 & Q2 & PI167195a_Turkey_Q2 \\
\hline PI167434 & Belgium & & 4.1 & Q2 & PI167434_Belgium_Q2 \\
\hline PI169026 & Turkey & & 4.7 & Q1 & PI169026_Turkey_Q1 \\
\hline PI169668 & Turkey & & 7.7 & Q1 & PI169668_Turkey_Q1 \\
\hline PI169669 & Turkey & & 5.3 & Q2 & PI169669_Turkey_Q2 \\
\hline PI169671 & Turkey & & 4.8 & Q1 & PI169671_Turkey_Q1 \\
\hline PI169673 & Turkey & & 9 & Q1 & PI169673_Turkey_Q1 \\
\hline PI169674 & Turkey & & 4.8 & Q1 & PI169674_Turkey_Q1 \\
\hline PI169675 & Turkey & & 5.4 & Q1 & PI169675_Turkey_Q1 \\
\hline PI169676 & Turkey & & 5.4 & Q1 & PI169676_Turkey_Q1 \\
\hline PI169677 & Turkey & & 5.9 & Q2 & PI169677_Turkey_Q2 \\
\hline PI169678 & Turkey & & 6.7 & Q1 & PI169678_Turkey_Q1 \\
\hline PI169680 & Turkey & & 5.8 & Q2 & PI169680_Turkey_Q2 \\
\hline PI169683 & Turkey & & 4.7 & Q2 & PI169683_Turkey_Q2 \\
\hline PI169684 & Turkey & & 5.9 & Q1 & PI169684_Turkey_Q1 \\
\hline PI169685 & Turkey & & 5 & Q1Q2 & PI169685_Turkey_Q1Q2 \\
\hline PI169686 & US & Maryland & 4.9 & $\mathrm{Q} 2$ & PI169686_Maryland_Q2 \\
\hline PI169688 & Turkey & & 4.6 & Q2 & PI169688_Turkey_Q2 \\
\hline PI169690 & Turkey & & 6.3 & Q1 & PI169690_Turkey_Q1 \\
\hline PI171859 & Turkey & & 5.7 & Q1 & PI171859_Turkey_Q1 \\
\hline PI171860 & Turkey & & 5 & Q2 & PI171860_Turkey_Q2 \\
\hline PI171862 & Turkey & & 10.8 & Q2 & PI171862_Turkey_Q2 \\
\hline PI171863 & Turkey & & 6.9 & $\mathrm{Q} 2$ & PI171863_Turkey_Q2 \\
\hline PI171864 & Turkey & & 4.3 & Q2 & PI171864_Turkey_Q2 \\
\hline PI171865 & Turkey & & 6.5 & Q1 & PI171865_Turkey_Q1 \\
\hline PI171866 & Turkey & & 8.3 & Q2 & PI171866_Turkey_Q2 \\
\hline PI173122 & Turkey & & 6.8 & $\mathrm{Q} 2$ & PI173122_Turkey_Q2 \\
\hline PI173123 & Turkey & & 6.6 & Q1 & PI173123_Turkey_Q1 \\
\hline PI173124 & Turkey & & 6.6 & Q1 & PI173124_Turkey_Q1 \\
\hline PI173125 & Turkey & & 6 & Q1 & PI173125_Turkey_Q1 \\
\hline PI173126 & Turkey & & 5.1 & $\mathrm{Q} 2$ & PI173126_Turkey_Q2 \\
\hline PI173127 & Turkey & & 6.3 & Q1Q2 & PI173127_Turkey_Q1Q2 \\
\hline PI173128 & Turkey & & 4.2 & $\mathrm{Q} 2$ & PI173128_Turkey_Q2 \\
\hline PI173129 & Turkey & & 3.9 & Q2 & PI173129_Turkey_Q2 \\
\hline
\end{tabular}




\begin{tabular}{|c|c|c|c|c|}
\hline PI173130 & Turkey & 7.4 & Q2 & PI173130_Turkey_Q2 \\
\hline PI173131 & Turkey & 8.7 & Q2 & PI173131_Turkey_Q2 \\
\hline PI173809 & Turkey & 3.1 & Q2 & PI173809_Turkey_Q2 \\
\hline PI173972 & India & 6.8 & Q2 & PI173972_India_Q2 \\
\hline PI174383 & Turkey & 5.3 & Q1 & PI174383_Turkey_Q1 \\
\hline PI174384 & Turkey & 5.9 & Q2 & PI174384_Turkey_Q2 \\
\hline PI174385 & Turkey & 10 & Q2 & PI174385_Turkey_Q2 \\
\hline PI174386 & Turkey & 6.8 & Q2 & PI174386_Turkey_Q2 \\
\hline PI174387 & Turkey & 5.5 & Q2 & PI174387_Turkey_Q2 \\
\hline PI174388 & Turkey & 4.3 & Q2 & PI174388_Turkey_Q2 \\
\hline PI174389 & Turkey & 6 & Q2 & PI174389_Turkey_Q2 \\
\hline PI174960 & India & 6.2 & Q1 & PI174960_India_Q1 \\
\hline PI175311 & India & 4.6 & Q2 & PI175311_India_Q2 \\
\hline PI175312 & India & 11.7 & Q1 & PI175312_India_Q1 \\
\hline PI175313 & India & 5.9 & Q2 & PI175313_India_Q2 \\
\hline PI175595 & Turkey & 3.1 & Q2 & PI175595_Turkey_Q2 \\
\hline PI175923 & Turkey & 7.1 & Q1 & PI175923_Turkey_Q1 \\
\hline PI175924 & Turkey & 6.4 & Q2 & PI175924_Turkey_Q2 \\
\hline PI175925 & Turkey & 5.3 & Q1 & PI175925_Turkey_Q1 \\
\hline PI175926 & Turkey & 6.5 & Q1 & PI175926_Turkey_Q1 \\
\hline PI175927 & Turkey & 6.5 & Q2 & PI175927_Turkey_Q2 \\
\hline PI175928 & Turkey & 4.4 & Q1 & PI175928_Turkey_Q1 \\
\hline PI175929 & Turkey & 5.6 & Q2 & PI175929_Turkey_Q2 \\
\hline PI175931 & Turkey & 5 & Q1 & PI175931_Turkey_Q1 \\
\hline PI175932 & Turkey & 4.9 & Q2 & PI175932_Turkey_Q2 \\
\hline PI176371 & Italy & 5.6 & Q1 & PI176371_Italy_Q1 \\
\hline PI176372 & Italy & 5.5 & Q1Q2 & PI176372_Italy_Q1Q2 \\
\hline PI176769 & Turkey & 4 & Q1 & PI176769_Turkey_Q1 \\
\hline PI176770 & Turkey & 4.4 & Q1 & PI176770_Turkey_Q1 \\
\hline PI176771 & Turkey & 7.3 & Q1 & PI176771_Turkey_Q1 \\
\hline PI176772 & Turkey & 3.6 & Q2 & PI176772_Turkey_Q2 \\
\hline PI176773 & Turkey & 5.9 & Q2 & PI176773_Turkey_Q2 \\
\hline PI176774 & Turkey & 6.1 & Q1 & PI176774_Turkey_Q1 \\
\hline PI176775 & Turkey & 4.2 & Q1 & PI176775_Turkey_Q1 \\
\hline PI176776 & Turkey & 4.1 & $\mathrm{Q} 2$ & PI176776_Turkey_Q2 \\
\hline PI176777 & Turkey & 5.6 & Q1Q2 & PI176777_Turkey_Q1Q2 \\
\hline PI176779 & Turkey & 6.7 & Q2 & PI176779_Turkey_Q2 \\
\hline PI176780 & Turkey & 5.9 & $\mathrm{Q} 2$ & PI176780_Turkey_Q2 \\
\hline PI177081 & Turkey & 4.9 & Q1Q2 & PI177081_Turkey_Q1Q2 \\
\hline PI177082 & Turkey & 5.4 & Q1 & PI177082_Turkey_Q1 \\
\hline PI177557 & Turkey & 4.3 & Q1 & PI177557_Turkey_Q1 \\
\hline PI177558 & Turkey & 7.6 & Q1 & PI177558_Turkey_Q1 \\
\hline PI179041 & Turkey & 3.9 & Q2 & PI179041_Turkey_Q2 \\
\hline
\end{tabular}




\begin{tabular}{|c|c|c|c|c|}
\hline PI179043 & Turkey & 5.7 & Q2 & PI179043_Turkey_Q2 \\
\hline PI179044 & Turkey & 5.6 & Q1 & PI179044_Turkey_Q1 \\
\hline PI179507 & Syria & 6.2 & Q2 & PI179507_Syria_Q2 \\
\hline PI179508 & Iraq & 6.2 & Q2 & PI179508_Iraq_Q2 \\
\hline PI179509 & Turkey & 4.3 & Q1 & PI179509_Turkey_Q1 \\
\hline PI179588 & Belgium & 7.2 & Q1 & PI179588_Belgium_Q1 \\
\hline PI179589 & Belgium & 7.3 & Q2 & PI179589_Belgium_Q2 \\
\hline PI179590 & Belgium & 5.3 & Q2 & PI179590_Belgium_Q2 \\
\hline PI179591 & Belgium & 4.5 & Q1 & PI179591_Belgium_Q1 \\
\hline PI179592 & Belgium & 4 & Q2 & PI179592_Belgium_Q2 \\
\hline PI179593 & Belgium & 4.8 & Q1 & PI179593_Belgium_Q1 \\
\hline PI179594 & Belgium & 3.6 & Q1Q2 & PI179594_Belgium_Q1Q2 \\
\hline PI179595 & Belgium & 4.4 & Q2 & PI179595_Belgium_Q2 \\
\hline PI179596 & Belgium & 6.9 & Q2 & PI179596_Belgium_Q2 \\
\hline PI179597 & Belgium & 4.3 & Q1 & PI179597_Belgium_Q1 \\
\hline PI181808 & Syria & 9.8 & Q1 & PI181808_Syria_Q1 \\
\hline PI181809 & Syria & 3.7 & Q2 & PI181809_Syria_Q2 \\
\hline PI181923 & Syria & 3.9 & Q1 & PI181923_Syria_Q1 \\
\hline PI181964 & Syria & 6.7 & Q2 & PI181964_Syria_Q2 \\
\hline PI184137 & Serbia & 4.5 & Q1 & PI184137_Serbia_Q1 \\
\hline PI192945 & China & 4.3 & Q1 & PI192945_China_Q1 \\
\hline PI193619 & Ethiopia & 4.7 & Q1 & PI193619_Ethiopia_Q1 \\
\hline PI200882 & Afghanistan & 8.4 & Q2 & PI200882_Afghanistan_Q2 \\
\hline PI204632 & Turkey & 5.8 & Q1 & PI204632_Turkey_Q1 \\
\hline PI204732 & Turkey & 5.5 & Q2 & PI204732_Turkey_Q2 \\
\hline PI204733 & Turkey & 8.1 & Q2 & PI204733_Turkey_Q2 \\
\hline PI204734 & Turkey & 7.6 & Q2 & PI204734_Turkey_Q2 \\
\hline PI204735 & Turkey & 6.2 & Q1 & PI204735_Turkey_Q1 \\
\hline PI204736 & Turkey & 5.8 & Q1 & PI204736_Turkey_Q1 \\
\hline PI205231 & Turkey & 4.7 & Q1Q2 & PI205231_Turkey_Q1Q2 \\
\hline PI205232 & Turkey & 4.7 & Q2 & PI205232_Turkey_Q2 \\
\hline PI205233 & Turkey & 7.2 & Q2 & PI205233_Turkey_Q2 \\
\hline PI205234 & Turkey & 6.8 & Q2 & PI205234_Turkey_Q2 \\
\hline PI205235 & Turkey & 8.8 & Q1 & PI205235_Turkey_Q1 \\
\hline PI206007 & Sweden & 7.8 & Q2 & PI206007_Sweden_Q2 \\
\hline PI206473 & Turkey & 3.9 & Q1 & PI206473_Turkey_Q1 \\
\hline PI206474 & Turkey & 7 & Q2 & PI206474_Turkey_Q2 \\
\hline PI206475 & Turkey & 6.6 & Q2 & PI206475_Turkey_Q2 \\
\hline PI206753 & Turkey & 9 & Q1 & PI206753_Turkey_Q1 \\
\hline PI207518 & Afghanistan & 4.3 & Q2 & PI207518_Afghanistan_Q2 \\
\hline PI209644 & Iran & 3.3 & Q1 & PI209644_Iran_Q1 \\
\hline PI209645 & Iran & 7.9 & Q2 & PI209645_Iran_Q2 \\
\hline PI209646 & Turkey & 9 & Q1Q2 & PI209646_Turkey_Q1Q2 \\
\hline
\end{tabular}




\begin{tabular}{|c|c|c|c|c|}
\hline PI209647 & Iran & 6.3 & Q2 & PI209647_Iran_Q2 \\
\hline PI211632 & Afghanistan & 6.2 & Q2 & PI211632_Afghanistan_Q2 \\
\hline PI212119 & Afghanistan & 5.7 & Q2 & PI212119_Afghanistan_Q2 \\
\hline PI212120 & Afghanistan & 6.4 & Q2 & PI212120_Afghanistan_Q2 \\
\hline PI212328 & Afghanistan & 5.2 & Q2 & PI212328_Afghanistan_Q2 \\
\hline PI217425 & SouthKorea & 5 & Q2 & PI217425_SouthKorea_Q2 \\
\hline PI219949 & Afghanistan & 3.4 & Q2 & PI219949_Afghanistan_Q2 \\
\hline PI220121 & Afghanistan & 1.1 & Q2 & PI220121_Afghanistan_Q2 \\
\hline PI220546 & Afghanistan & 6.3 & Q1 & PI220546_Afghanistan_Q1 \\
\hline PI220686 & Afghanistan & 4.1 & Q2 & PI220686_Afghanistan_Q2 \\
\hline PI222270 & Iran & 5.8 & Q2 & PI222270_Iran_Q2 \\
\hline PI222749 & Iran & 4.7 & Q2 & PI222749_Iran_Q2 \\
\hline PI222750 & Iran & 4.2 & Q2 & PI222750_Iran_Q2 \\
\hline PI222838 & Iran & 4.2 & Q1 & PI222838_Iran_Q1 \\
\hline PI223536 & Afghanistan & 11.2 & Q2 & PI223536_Afghanistan_Q2 \\
\hline PI224959 & Iran & 6 & Q1 & PI224959_Iran_Q1 \\
\hline PI226671 & Iran & 3.4 & Q1 & PI226671_Iran_Q1 \\
\hline PI227045 & Iran & 3.5 & Q1 & PI227045_Iran_Q1 \\
\hline PI227230 & Japan & 6.1 & Q1 & PI227230_Japan_Q1 \\
\hline PI227383 & Iran & 6.1 & Q1 & PI227383_Iran_Q1 \\
\hline PI229731 & Iran & 7.9 & Q2 & PI229731_Iran_Q2 \\
\hline PI229792 & Iran & 7.7 & Q1 & PI229792_Iran_Q1 \\
\hline PI249920 & Spain & 3.1 & Q1 & PI249920_Spain_Q1 \\
\hline PI251507 & Iran & 3.8 & Q2 & PI251507_Iran_Q2 \\
\hline PI254565 & Afghanistan & 5.4 & Q2 & PI254565_Afghanistan_Q2 \\
\hline PI256079 & Afghanistan & 3.6 & Q1Q2 & PI256079_Afghanistan_Q1Q2 \\
\hline PI261788 & France & 3.1 & Q1 & PI261788_France_Q1 \\
\hline PI261789 & France & 6.1 & Q2 & PI261789_France_Q2 \\
\hline PI262161 & Spain & 3.7 & Q2 & PI262161_Spain_Q2 \\
\hline PI262911 & Spain & 5.1 & Q2 & PI262911_Spain_Q2 \\
\hline PI263873 & Greece & 4.3 & Q2 & PI263873_Greece_Q2 \\
\hline PI266926 & Germany & 3.7 & Q2 & PI266926_Germany_Q2 \\
\hline PI274042 & England & 3.9 & Q2 & PI274042_England_Q2 \\
\hline PI274044 & England & 3.4 & Q1 & PI274044_England_Q1 \\
\hline PI274046 & England & 3.5 & Q2 & PI274046_England_Q2 \\
\hline PI274047 & England & 5.1 & Q2 & PI274047_England_Q2 \\
\hline PI274048 & England & 4.7 & Q2 & PI274048_England_Q2 \\
\hline PI274049 & England & 3.6 & Q1 & PI274049_England_Q1 \\
\hline PI274050 & England & 5.4 & Q2 & PI274050_England_Q2 \\
\hline PI274051 & England & 4.8 & Q2 & PI274051_England_Q2 \\
\hline PI274052 & England & 3.6 & Q2 & PI274052_England_Q2 \\
\hline PI274053 & England & 4.4 & Q2 & PI274053_England_Q2 \\
\hline PI274055 & England & 5.4 & Q2 & PI274055_England_Q2 \\
\hline
\end{tabular}




\begin{tabular}{|c|c|c|c|c|}
\hline PI274056 & England & 3.6 & Q2 & PI274056_England_Q2 \\
\hline PI274057 & England & 5.1 & Q2 & PI274057_England_Q2 \\
\hline PI274058 & England & 2.7 & Q2 & PI274058_England_Q2 \\
\hline PI274059 & England & 2 & Q2 & PI274059_England_Q2 \\
\hline PI274060 & England & 5.4 & Q2 & PI274060_England_Q2 \\
\hline PI274063 & England & 4.7 & Q2 & PI274063_England_Q2 \\
\hline PI274065 & England & 2.8 & Q2 & PI274065_England_Q2 \\
\hline PI285751 & Warszawa & 3.6 & Q2 & PI285751_Warszawa_Q2 \\
\hline PI296393 & Iran & 5.1 & Q1Q2 & PI296393_Iran_Q1Q2 \\
\hline PI303138 & Netherlands & 6.4 & Q2 & PI303138_Netherlands_Q2 \\
\hline PI319220 & Egypt & 3.1 & Q2 & PI319220_Egypt_Q2 \\
\hline PI321020 & China & 3.9 & Q2 & PI321020_China_Q2 \\
\hline PI339545 & Turkey & 2.6 & Q2 & PI339545_Turkey_Q2 \\
\hline PI339546 & Turkey & 3.9 & Q2 & PI339546_Turkey_Q2 \\
\hline PI339547 & Turkey & 4.1 & Q2 & PI339547_Turkey_Q2 \\
\hline PI339548 & Turkey & 3.9 & Q2 & PI339548_Turkey_Q2 \\
\hline PI358248 & Serbia & 1.9 & Q2 & PI358248_Serbia_Q2 \\
\hline PI358249 & Serbia & 5.4 & Q1 & PI358249_Serbia_Q1 \\
\hline PI358250 & Serbia & 4.5 & Q1 & PI358250_Serbia_Q1 \\
\hline PI358251 & Serbia & 4.6 & Q2 & PI358251_Serbia_Q2 \\
\hline PI358252 & Serbia & 5.5 & Q2 & PI358252_Serbia_Q2 \\
\hline PI358253 & Serbia & 2.7 & Q1 & PI358253_Serbia_Q1 \\
\hline PI358254 & Serbia & 4.5 & Q2 & PI358254_Serbia_Q2 \\
\hline PI358256 & Serbia & 7.5 & Q2 & PI358256_Serbia_Q2 \\
\hline PI358257 & Serbia & 6.2 & Q2 & PI358257_Serbia_Q2 \\
\hline PI358258 & Macedonia & 5.8 & Q2 & PI358258_Macedonia_Q2 \\
\hline PI358259 & Serbia & 3.2 & Q1 & PI358259_Serbia_Q1 \\
\hline PI358260 & Macedonia & 5.3 & Q2 & PI358260_Macedonia_Q2 \\
\hline PI360710 & France & 5.8 & Q2 & PI360710_France_Q2 \\
\hline PI360895 & Netherlands & 3.2 & Q2 & PI360895_Netherlands_Q2 \\
\hline PI361127 & England & 5.3 & Q2 & PI361127_England_Q2 \\
\hline PI368824 & Serbia & 5.7 & Q2 & PI368824_Serbia_Q2 \\
\hline PI368825 & Serbia & 5 & Q2 & PI368825_Serbia_Q2 \\
\hline PI368826 & Serbia & 7.9 & Q2 & PI368826_Serbia_Q2 \\
\hline PI370602 & Serbia & 9 & Q2 & PI370602_Serbia_Q2 \\
\hline PI374233 & Egypt & 3.7 & Q1 & PI374233_Egypt_Q1 \\
\hline PI379546 & Serbia & 3.6 & Q2 & PI379546_Serbia_Q2 \\
\hline PI379547 & Serbia & 3.8 & Q2 & PI379547_Serbia_Q2 \\
\hline PI379548 & Serbia & 5.5 & Q2 & PI379548_Serbia_Q2 \\
\hline PI379549 & Serbia & 3.7 & Q2 & PI379549_Serbia_Q2 \\
\hline PI379550 & Serbia & 4.5 & Q1 & PI379550_Serbia_Q1 \\
\hline PI379551 & Serbia & 3.9 & Q2 & PI379551_Serbia_Q2 \\
\hline PI379552 & Serbia & 5.2 & Q2 & PI379552_Serbia_Q2 \\
\hline
\end{tabular}




\begin{tabular}{|c|c|c|c|c|}
\hline PI418978 & China & 5.1 & Q2 & PI418978_China_Q2 \\
\hline PI419004 & China & 6.9 & Q2 & PI419004_China_Q2 \\
\hline PI419162 & china & 4.1 & Q2 & PI419162_china_Q2 \\
\hline PI419218 & China & 4.8 & Q2 & PI419218_China_Q2 \\
\hline PI433207 & China & 5.2 & Q2 & PI433207_China_Q2 \\
\hline PI433208 & China & 10.6 & Q2 & PI433208_China_Q2 \\
\hline PI433209 & China & 7.4 & Q2 & PI433209_China_Q2 \\
\hline PI433210 & China & 7.4 & Q2 & PI433210_China_Q2 \\
\hline PI433211 & France & 4.6 & Q2 & PI433211_France_Q2 \\
\hline PI433212 & China & 6.3 & Q1 & PI433212_China_Q1 \\
\hline PI445782 & Syria & 8.8 & Q2 & PI445782_Syria_Q2 \\
\hline PI445783 & Syria & 1.6 & Q2 & PI445783_Syria_Q2 \\
\hline PI445784 & Syria & 5.1 & Q2 & PI445784_Syria_Q2 \\
\hline PI445785 & Syria & 5.6 & Q2 & PI445785_Syria_Q2 \\
\hline PI449353 & Turkey & 2 & Q2 & PI449353_Turkey_Q2 \\
\hline PI478393 & China & 3.5 & Q1 & PI478393_China_Q1 \\
\hline PI491261 & Greece & 5.4 & Q2 & PI491261_Greece_Q2 \\
\hline PI491262 & Greece & 5 & Q2 & PI491262_Greece_Q2 \\
\hline PI499372 & SovietUnion & 3.2 & Q2 & PI499372_SovietUnion_Q2 \\
\hline PI499373 & SovietUnion & 4.1 & Q1Q2 & PI499373_SovietUnion_Q1Q2 \\
\hline PI508504 & SouthKorea & 6.5 & Q1 & PI508504_SouthKorea_Q1 \\
\hline PI527332 & China & 2.6 & Q2 & PI527332_China_Q2 \\
\hline PI531448 & Hungary & 3 & Q2 & PI531448_Hungary_Q2 \\
\hline PI531449 & Hungary & 2.7 & Q1 & PI531449_Hungary_Q1 \\
\hline PI531450 & Hungary & 3.1 & Q2 & PI531450_Hungary_Q2 \\
\hline PI531452 & Denmark & 5.1 & Q1 & PI531452_Denmark_Q1 \\
\hline PI531453 & Hungary & 3.5 & Q2 & PI531453_Hungary_Q2 \\
\hline PI531454 & Hungary & 1.9 & Q2 & PI531454_Hungary_Q2 \\
\hline PI531456 & Hungary & 3 & Q2 & PI531456_Hungary_Q2 \\
\hline PI531457 & Hungary & 2.7 & Q2 & PI531457_Hungary_Q2 \\
\hline PI535897 & Poland & 3.7 & Q1 & PI535897_Poland_Q1 \\
\hline PI604777 & Japan & 4.5 & Q1 & PI604777_Japan_Q1 \\
\hline PI604778 & Japan & 9.3 & Q1 & PI604778_Japan_Q1 \\
\hline PI604779 & Japan & 5.6 & Q2 & PI604779_Japan_Q2 \\
\hline PI604780 & Japan & 5.3 & Q2 & PI604780_Japan_Q2 \\
\hline PI604782 & Afghanistan & 4 & Q1 & PI604782_Afghanistan_Q1 \\
\hline PI604783 & Afghanistan & 2.5 & Q2 & PI604783_Afghanistan_Q2 \\
\hline PI604784 & Afghanistan & 3.3 & Q2 & PI604784_Afghanistan_Q2 \\
\hline PI604785 & Mongoli & 4.3 & Q1 & PI604785_Mongoli_Q1 \\
\hline PI604786 & Nepal & 5.5 & Q1 & PI604786_Nepal_Q1 \\
\hline PI604787 & Afghanistan & 2.9 & Q1 & PI604787_Afghanistan_Q1 \\
\hline PI604788 & Afghanistan & 4.1 & Q2 & PI604788_Afghanistan_Q2 \\
\hline PI604789 & Afghanistan & 2.4 & Q2 & PI604789_Afghanistan_Q2 \\
\hline
\end{tabular}




\begin{tabular}{lllll} 
PI604790 & Afghanistan & 3.4 & Q2 & PI604790_Afghanistan_Q2 \\
PI604791 & Afghanistan & 2.4 & Q2 & PI604791_Afghanistan_Q2 \\
PI606707 & Netherlands & 4.6 & Q2 & PI606707_NorthHolland_Q2 \\
PI608762 & Thailand & 8.8 & Q2 & PI608762_Thailand_Q2 \\
\hline
\end{tabular}

${ }^{a}$ Leaf damage signifies the mean strings per square centimeter leaf area for each spinach genotype.

${ }^{\mathrm{b}}$ Two population structures (Clusters) identified from Mega 6: Q1 means that the spinach accession belongs to the population group1; Q2 to group2; and Q1Q2 to group 1 or 2.

${ }^{\mathrm{c}}$ In order to view the phylogenetic trees easily, the spinach accession number, the accession original country, the accession geography region, and the structure population (cluster) were merged together into one taxon name as each spinach accession in drawing the combined tree. For example, the taxon name, Ames23662_Afghanistan_Q2 includes the accession number - Ames23662, which was originally collected from Afghanistan; and assigned to cluster Q2, where there were a total of two clusters and mixtrue. 
Supplementary Fig. S1. The traditional phylogenetic tree combining structure populations (Q1 to Q2) from STRCTURE 2 and the Maximum Likelihood (ML) method from MEGA 6. The spinach accession number, the accession original country (or the State in US), and the structure population (cluster) were merged together into one taxon name as each spinach accession in the combined tree drawn by MEGA. The colored shape and branch are one cluster that matched the structure population (red for Q1, green for Q2, and the empty black square for the admixture Q1Q2). 


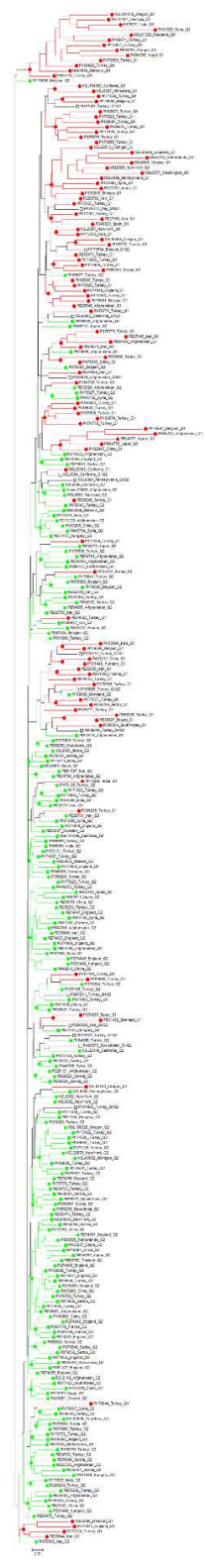

$152 \times 1202 \mathrm{~mm}(96 \times 96 \mathrm{DPI})$ 